\title{
Eksplorasi Nilai-Nilai Asthabrata Sebagai Pendidikan Antikorupsi
}

\author{
Rizki Rian Sari \\ Universitas Sebelas Maret \\ riririanrizki98@student.uns.ac.id
}

\section{Article History}

received $1 / 9 / 2021$

revised $1 / 10 / 2021 \quad$ accepted $1 / 11 / 2021$

\begin{abstract}
Penelitian ini bertujuan untuk mengetahui pendidikan antikorupsi berlandaskan nilai-nilai filosofi Astha brata. Metode yang digunakan dalam penelitian ini adalah metode kualitatif diskriptif. Sumber data diperoleh melalui studi kepustakaan. Nilai-nilai yang terkandung dalam Astha Brata menjadi pedoman dalam menyelenggarakan pendidikan antikorupsi. Salah satu tujuan pendidikan antikorupsi adalah menyiapkan pemimpin masa depan yang bebas dari tindakan korupsi. Nilai-nilai yang terkandung dalam Astha brata sebagai bentuk pengendalian diri bagi seorang pemimpin. Pemimpin yang tidak memiliki landasan yang kuat dalam diri maka akan mudah tergoda oleh materi yang berada disekitarnya. Seorang pemimpin tidak bisa dipisahkan dari materi. Dengan materi tersebut, tentu tidak semua menjadi haknya, jika tidak memiliki pengendalian diri yang kuat maka mudah sekali melakukan tindakan korupsi. Oleh karena itu, seorang pemimpin yang ideal diharapkan memiliki sifat dari delapan dewa dalam agama Hindu yang terdiri dari Indra Brata, Yama Brata, Surya Brata, Candra Brata, Bayu Brata, Kuwera Brata, Baruna Brata, dan Agni Brata. Di dalam nilai tersebut mengandung makna bagaimana menjadi pemimpin yang ideal yang bisa dicontoh.
\end{abstract}

Keywords: Nilai-nilai Astha Brata, Kepemimpinan, Pendidikan Antikorupsi

\section{Abstrak}

This study aims to determine anti-corruption education based on the philosophical values of Astha Brata. The method used in this research is descriptive qualitative method. Sources of data obtained through literature study. The values contained in Astha Brata serve as guidelines in conducting anti-corruption education. On of the goal of anti-corruption education is to prepare future leaders who are free from corruption. The values contained in Astha Brata as a form of self control for a leader. Leader who do not have a strong foundation in themselves will be easy tempted by the material around them. A leader can not be separated from the material. with these materials, of course, not all of them become their rights, if they do not have strong selfcontrol. It is easy to commit acts of the eight gods in Hinduism consisting of Indra Brata, Yama Brata, Surya Brata, Candra Brata, Bayu Brata, Kuwera Brata, Baruna Brata, dan Agni Brata. This values contains the meaning of how to be an ideal leader who can be emulated.

Kata kunci: Astha Brata Values, Leadership, Anti-corruption Education

Social, Humanities, and Education Studies (SHEs): Conference Series https://jurnal.uns.ac.id/shes 


\section{PENDAHULUAN}

Indonesia adalah negara yang sedang berjuang dalam melawan korupsi. Korupsi adalah bentuk penyimpangan yang dapat merugikan masyarakat negara pada umumnya. Pemerintah adalah unsur penting yang berperan dalam upaya memberantas korupsi. Di dalam pemerintahan ada pemimpin yang menggerakkan arah pemerintahan. Seorang pemimpin harus memiliki visi misi atas pendirian dan komitmen serta bertanggung jawab dengan tugas yang ditanggungnya (Rai Bagus \& Suarningsih, 2019: 2). Namun pada kenyataanya saat ini masih ada kasus korupsi di Indonesia yang dilakukan oleh pemimpin. Salah satu contoh tindakan korupsi menurut Kompasiana.com (10 Januari 2014) terjadi kasus suap menyuap yang dilakukan oleh mantan Gubernur Banten Ratu Atut Chosiyah terhadap Hakim MK Akil Mochtar untuk menyelesaikan kasus sengketa pilkada Banten.

Berbagai upaya pemberantasan korupsi sudah dilakukan dengan berbagai cara, seperti memberikan sanksi yang berat terhadap pelaku korupsi. Pada kenyataanya, berita mengenai penangkapan pelaku korupsi masih terjadi (Setiadi, 2018:250). Menurut wartawan terkenal, Mukhtar Lubis yang dikutip dalam Ka'bah (2007:77) bahwa pada tahun tujuh puluhan korupsi telah menjadi budaya bangsa Indonesia. Budaya adalah hasil cipta dan karsa manusia. Korupsi disebut sebagai budaya mempunyai arti bahwa orang Indonesia pada umumnya telah menjadi makhluk yang rakus, tidak lagi patuh kepada norma agama dan hukum, tidak mengetahui sopan santun, atau telah hidup seperti binatang yang hanya memikirkan diri sendiri. Menurut Hamzah Andi (1991: 7) jika korupsi telah merajalela dan menjadi makanan setiap hari masyarakat, akan menyebabkan kondisi masyarakat yang kacau. Hal tersebut disebabkan karena tidak ada sistem sosial yang berlaku dengan baik. Setiap individu dalam masyarakat hanya mementingkan diri sendiri (self interest).

Salah satu upaya yang bisa dilakukan untuk mencegah tindakan korupsi adalah mengadakan pendidikan antikorupsi sejak dini. Pendidikan ini bisa berawal dari kegiatan-kegiatan sederhana yang dilakukan di lingkungan seperti menanamkan budaya takut, disiplin dan bertanggungjawab (Suciartini, tt: 53). Pembudayaan lain juga bisa dilakukan di pendidikan formal maupun non formal dari guru ke murid, orang tua ke anak cucu maupun dari tokoh ke masyarakat umum dan lainnya. Budaya berperan dalam pendidikan antikorupsi. Salah satu budaya yang menjadi kearifan lokal Indonesia adalah konsep Asthabrata. Nilai-nilai yang terkandung dalam Asthabrata dapat menjadi pedoman dalam menjadi pemimpin yang ideal. Nilai tersebut dapat menjadi teladan dalam kepemimpinan dalam mencegah perilaku tindak pidana korupsi. Oleh karena itu, dalam tulisan ini akan membahas mengenai nilai-nilai Asthabrata sebagai pendidikan antikorupsi.

\section{METODE}

Penelitian ini merupakan penelitian deskriptif dengan metode penelitian kualitatif. Sumber data diperoleh dengan melakukan studi kepustakaan yaitu bukubuku, jurnal, skripsi, tesis, maupun artikel ilmiah yang berkaitan. Teknik analisis data menggunakan model analisis interaktif kualitatif yaitu pengumpulan data, reduksi data, penyajian data, dan penarikan kesimpulan.

\section{a. Nilai}

\section{HASIL DAN PEMBAHASAN}

Nilai adalah standar ukuran atau norma yang digunakan untuk mengukur sesuatu. Menurut KBBI (2021: 963) nilai adalah sifat- sifat atau hal-hal yang penting dan berguna bagi kemanusiaan. Nilai tersebut disebut juga sebagai sesuatu yang menyempurnakan manusia sesuai dengan hakikatnya. Dalam hal ini, misalnya nilai etik, yaitu nilai untuk manusia sebagai pribadi yang utuh. Nilai etik contohnya adalah kejujuran yang berkaitan dengan akhlak dan benar salah yang dianut sekelompok manusia. Dalam kehidupan sehari-hari, nilai merupakan sesuatu yang berharga, 
bermutu, menunjukkan kualitas, dan berguna bagi manusia. Menurut Frankel yang dikutip dalam Sukitman (2016:87) nilai adalah standar tingkah laku, keindahan, keadilan, kebenaran, dan efisiensi yang mengikat manusia dan sepatutnya untuk dijalankan dan dipertahankan.

Dari pengertian diatas, dapat disimpulkan bahwa nilai adalah sesuatu yang melekat pada diri manusia. Nilai harus dijalankan dan dipertahankan sebagai makhluk ciptaan Tuhan. Nilai sebagai ciri khas manusia yang membedakan dengan makhluk lain. Manusia mempunyai perasaan, akal, kasih sayang, hati nurani, moral, budi pekerti serta etika yang melekat pada diri manusia sebagai bentuk dari nilai itu sendiri.

b. Pendidikan

Pendidikan adalah upaya sadar untuk menyiapkan peningkatan kehidupan peserta didik yang mandiri dan berbudaya harmonis, yaitu memiliki moral dan akhlak mulia, profesi yang dilandasi ilmu pengetahuan, teknologi dan atau seni tepat guna, dan memiliki kreativitas terpuji yang menyejukkan dan membawa kedamaian yang bernilai indah, sehingga kehidupannya lebih baik. Pendidikan menjadi tanggung jawab bersama, antara keluarga, masyarakat dan pemerintah melalui sekolah, baik yang dikelola oleh pemerintah sendiri maupun oleh masyarakat. Pendidikan bertujuan mendorong perubahan kemampuan seseorang. Perubahan secara langsung terhadap kualitas kemampuan kognitif, afektif, dan psikomotor. Peningkatan dalam ketiga macam kawasan tersebut tidak sekedar untuk meningkatkan belaka, tetapi suatu peningkatan yang hasilnya dapat dipergunakan untuk lebih meningkatkan taraf hidupnya sebagai pribadi, pekerja/ profesional, warga masyarakat dan warga negara dan makhluk Tuhan (Rahmad, Abdul. 2010:16)

c. Kepemimpinan

Menurut Hersey dan Blanchard, pemimpin adalah seseorang yang dapat mempengaruhi orang lain atau kelompok untuk melakukan unjuk kerja maksimum yang telah ditetapkan sesuai dengan tujuan organisasi. Sedangkan kepemimpinan merupakan suatu proses dengan berbagai cara mempengaruhi orang atau sekelompok orang untuk mencapai suatu tujuan bersama (Chaniago,2017:87). Kepemimpinan merupakan bagian dari fungsi-fungsi manajemen yang menduduki posisi strategis dalam sistem dan hierarki kerja dan tanggung jawab pada sebuah organisasi. Menurut Vietzal Rivai dan Boy Raffi Amar (2013:21) Seorang pemimpin dalam suatu organisasi harus memiliki kriteria tertentu layaknya seorang pemimpin yang sejati kriteria tersebut, yaitu: Pengaruh, Kekuasaan/power, wewenang, pengikut. Kepemimpinan adalah kemampuan yang dapat mempengaruhi bawahan atau kelompok untuk bekerja sama mencapai tujuan organisasi atau kelompok.

\section{Eksplorasi Nilai-Nilai Astabrata}

Secara etimologis kata Astha Brata berasal dari bahasa Sansekerta, Astha berarti delapan dan Brata berarti laku atau pedoman. Kata Astha Brata berasal dari kitab Manawa Dharma Sastra atau kitab hukum Hindu yang ditulis dalam bahasa Sansekerta. Kitab ini dihimpun oleh Bhagawan Bhirgu yang diajarkan oleh Manu, seorang pemuka agama Hindu. Kitab ini menyebutkan bahwa seorang raja harus bertindak berlandaskan pada kedelapan sifat dewa (As'ad, Anggoro \&Virdaniaty, 2011:229). Astha Brata merupakan suatu ajaran, petunjuk atau nasehat kepemimpinan yang diberikan oleh Sri Rama kepada sang Wibisana pada waktu penobatannya menjadi Raja di Negeri Alengka Pura (Aryawan, 2021:57).

Ajaran Asthabrata terdapat dalam beberapa karya sastra Jawa, antara lain kitab Nitisruti, Serat Rama Jarwa, Babad Sangkala, Serat Pakem Makutharama, dan Serat Partawigena. Ajaran Astha Brata yang dikenal secara umum saat ini memuat delapan ajaran perilaku kepemimpinan yang disimbolkan dengan sifat-sifat dewa alam, yaitu: langit, matahari, angin, air, samudra, bulan, bintang dan api. Namun pada dasarnya terjadi pergeseran ajaran Asthabrata yang terlihat dari muatan teks-teks Jawa, dari yang sebelumnya simbolisasi sifat dewa alam menjadi sifat alam saja. Sifat- 
sifat dewa dalam Asthabrata merupakan simbolisasi dari sifat elemen alam semesta yang patut dijadikan pedoman bagi setiap pemimpin. Nilai-nilai yang terkandung dalam Asthabrata dieksplorasi sebagai berikut:

1. Indra Brata: Indra merupakan dewa yang menghujani bumi, ia merupakan dewa yang paling penting di langit. Seorang Pemimpin hendaknya seperti hujan. Pemimpin senantiasa mengusahakan kemakmuran bagi rakyatnya dan setiap perilaku membawa kesejukan dan penuh kewibawaan. Langit merupakan atap bagi bumi. Langit adalah cakrawala. la adalah simbol bagi luasnya ilmu pengetahuan. Sosok yang menyimbolkan langit memiliki kompetensi, kemampuan, dan kecakapan yang dapat diajarkan pada orang lain.

2. Yama Brata: Dewa Yama disimbolkan sebagai penjaga negara agung. la selalu menindak seluruh kejahatan tanpa pandang bulu meskipun terhadap kerabat sendiri. Pemimpin harus berperilaku adil dalam menerapkan hukum, menjaga kebenaran, dan berani bertindak tegas untuk menjatuhkan hukuman kepada siapapun yang berbuat salah dan mengganggu keamanan negaranya.

3. Surya Brata: Surya merupakan pengendalian diri sesuai dengan sifat dewa Matahari. Matahari adalah sumber cahaya bagi kehidupan makhluk. Matahari adalah sumber kehidupan yang memberikan sinarnya tanpa pilih kasih. Seorang pemimpin harus memberikan bimbingan dan pendidikan agar manusia terhindar dari kegelapan tanpa pilih kasih maupun membeda-bedakan pangkat dan golongannya. Memberi seperti matahari adalah memberi dengan terus menerus, hingga ia tidak menyadari bahwa telah berbuat banyak untuk orang lain.

4. Candra Brata: Dewa Candra menggambarkan sifat bulan yang memancarkan sinar dengan lembut. Pemimpin hendaknya memiliki sikap lemah lembut, ramah tamah, murah senyum serta tidak mudah marah. Ketika memandang bulan, ada rasa damai dalam gelap. Pemimpin harus menjadi sosok yang memberikan kedamaian pada sekitarnya. Rasa damai tersebut membuat nyaman dan membuat hati gembira.

5. Bayu Brata: Dewa Bayu menggambarkan sifat angin. Angin atau udara merupakan sesuatu yang berguna bagi manusia untuk bisa bernafas. Angin juga memberikan kesejukan pada manusia agar terhindar dari panas atau gerah. Pemimpin diharapkan dapat menciptakan suasana sejuk, segar sehingga terjalin kerjasama yang baik. Angin dapat berhembus di mana saja. Angin terbentuk ketika ada perbedaan tekanan udara. Pemimpin yaitu seseorang keberadaan dan pengaruhnya bisa dirasakan oleh sekitarnya. Keberadaan pemimpin bukan sebagai simbol dari kekuasaan. Pemimpin harus terjun menghadapi masalah dan peduli pada kondisi yang dihadapi.

6. Kuwera Brata: Dewa Kuwera disejajarakan dengan pemimpin yang berwatak bumi, ia yang menyangga bumi. Setiap makhluk memiliki hak untuk hidup di bumi dan bumi harus lapang dada menerima semua tugas kewajibannya dalam melayani semua orang dengan berbagai status yang berbeda. Dewa Kuwera merupakan contoh yang dapat diteladani yaitu menjaga dan mempergunakan harta kekayaan dengan sebaik-baiknya untuk kepentingan kesejahteraan manusia dan kebahagiaan dalam tata cara pengendalian diri. Harta atau kekayaan harus dipakai untuk tujuan yang baik, bukan untuk menyombongkan diri. Seorang pemimpin harus mengelola, memelihara, dan menjaga harta benda yang dipercayakan kepadanya dengan baik demi kesejahteraan masyarakatnya.

7. Baruna Brata: Dewa Baruna memiliki sifat kemanapun ia pergi selalu membawa nagapasa, senjata yang sangat sakti. Sifat ini merupakan lambang bahwa seorang pemimpin harus siap siaga dalam menjalankan tugas menjaga keamanan dan kedamaian negara. Dewa Baruna disejajarkan seperti samudra, samudra adalah hilir untuk semua sungai, padahal tidak semua air disungai bersih. Oleh karena itu, samudra menerima air dari sungai manapun, baik itu kotor atau bersih. Seperti samudra, pemimpin adalah sosok yang membuka mata dan pikiran secara luas. 
Pemimpin bisa menerima pendapat dari sekitar sebagai bentuk menghargai seorang pemimpin pada orang lain.

8. Agni Brata: api membakar apa saja yang menyentuhnya, jadi api memiliki hukum yang jelas. Walaupun api bersifat merusak, tetapi ia merupakan unsur alam yang paling adil diantara yang lain. Api bersifat spontan namun stabil dalam mencerminkan keberanian dan memiliki keyakinan kuat. Berani serta yakin untuk menghancurkan masalah-masalah yang muncul dikemudian hari. Api bersifat tegas dalam menghadapi masalah dan merepresentasikan ketegasan dalam pengelolaan mengambil keputusan.

\section{Pendidikan Antikorupsi}

Secara umum, pendidikan antikorupsi diartikan sebagai pendidikan koreksi budaya yang bertujuan untuk mengenalkan cara berpikir dan nilai-nilai baru kepada peserta didik (Suyanto, 2005: 43). Cara berpikir dan nilai-nilai baru penting disosialisasikan atau ditanamkan kepada peserta didik karena gejala korupsi di masyarakat sudah membudaya dan dikhawatirkan para generasi muda menganggap korupsi sebagai hal biasa. Bagi peserta didik yang masih menimba pendidikan, pendekatannya diarahkan pada pembentukan moralitas dan penguatan kesadaran sosial, termasuk pembentukan mentalitas dan karakter yang bersih dari perilaku dan tindakan koruptif. Sehingga ketika mereka menjadi pejabat di kelak kemudian hari, tidak melakukan korupsi. Mereka menjadi pejabat yang betul-betul bekerja untuk rakyat (pamong praja), menggunakan uang negara untuk sebesar-besar kemakmuran rakyat dan kemajuan bangsa.

Pendidikan antikorupsi dapat dipahami juga sebagai usaha sadar dan sistematis yang diberikan kepada peserta didik berupa pengetahuan, nilai-nilai, sikap dan keterampilan yang dibutuhkan agar mereka mau dan mampu mencegah dan menghilangkan peluang berkembangnya korupsi. Sasaran akhir bukan hanya menghilangkan peluang, tetapi juga peserta didik sanggup menolak segala pengaruh yang mengarah pada perilaku koruptif (Handoyo, Eko. 2013:43).

Menurut Azra (2006: viii) pendidikan antikorupsi diperlukan untuk memperkuat pemberantasan korupsi yang sedang berjalan. Upaya ini dilakukan melalui reformasi sistem (constitutional reform) dan reformasi kelembagaan (institutional reform) serta penegakan hukum (law enforcement). Pendidikan antikorupsi sebagai upaya reformasi kultur politik melalui sistem pendidikan untuk melakukan perubahan kultural yang berkelanjutan. Kultur tersebut termasuk mendorong terciptanya good governance culture di sekolah dan perguruan tinggi. Sekolah atau perguruan tinggi dapat mengambil peran strategis dalam melaksanakan pendidikan antikorupsi terutama dalam membudayakan perilaku antikorupsi di kalangan siswa dan mahasiswa. Melalui pengembangan kultur sekolah, diharapkan siswa-siswa memiliki modal sosial untuk membiasakan berperilaku antikorupsi.

Nilai-nilai antikorupsi perlu ditanamkan pada jiwa dan roh generasi muda agar menjadi bekal kelak ketika menjadi pemimpin. Menurut Handoyo (2013:34-43) nilainilai antikorupsi yang perlu disemaikan kepada generasi muda, terutama mereka yang masih duduk di bangku TK, SD, SMP, SMA, dan Perguruan Tinggi antara lain:

a. Kejujuran, kejujuran merupakan dasar setiap usaha untuk menjadi orang kuat secara moral. Tanpa kejujuran, manusia tidak dapat maju selangkah pun, karena ia tidak berani menjadi diri sendiri

b. Tanggung Jawab, Bertanggung jawab berarti suatu sikap terhadap tugas yang membebani kita, dimana kita merasa terikat untuk menyelesaikannya demi tugas itu sendiri

c. Keberanian, Keberanian berasal dari kata berani, yang artinya mempunyai hati yang mantap dan rasa percaya diri yang besar dalam menghadapi bahaya, kesulitan, dan sebagainya. 
d. Keadilan, Keadilan berasal dari kata adil, artinya sama berat, tidak berat sebelah, tidak memihak; berpihak kepada yang benar, berpegang pada kebenaran; sepatutnya, tidak sewenang-wenang

e. Keterbukaan, Nilai keterbukaan berkaitan erat dengan kejujuran. Terbuka tidak berarti bahwa segala pertanyaan orang lain harus kita jawab selengkaplengkapnya atau orang lain berhak untuk mengetahui segala perasaan dan pikiran kita

f. Kedisiplinan, Kedisiplinan berasal dari kata disiplin, artinya tata tertib, ketaatan kepada peraturan. Disiplin merupakan kunci sukses, sebab dalam disiplin akan tumbuh sifat yang teguh dalam memegang prinsip, pantang mundur dalam menyatakan kebenaran, dan pada akhirnya mau berkorban untuk kepentingan bangsa dan negara

g. Kesederhanaan, Kesederhanaan adalah sikap dan perilaku yang tidak berlebihan terhadap suatu benda, tetapi lebih mementingkan tujuan dan manfaatnya

h. Kerja Keras, Dengan demikian, bekerja keras berarti melakukan sesuatu secara bersungguh-sungguh. Pribadi pekerja keras akan muncul dari sosok yang memiliki motivasi tinggi untuk berubah dan pantang menyerah dalam segala keadaan.

i. Kepedulian, Kepedulian bermakna berperilaku dan memperlakukan orang lain dan lingkungan sekitarnya, sehingga bermanfaat bagi semua pihak

Nilai-nilai tersebut dapat diperoleh salah satunya adalah melalui budaya. Budaya berperan dalam pendidikan antikorupsi. Salah satu budaya yang menjadi kearifan lokal Indonesia adalah konsep Asthabrata. Konsep Asthabrata menjadi kearifan bagi masyarakat Bali. Nilai-nilai yang terkandung dalam Asthabrata dapat menjadi pedoman dalam menjadi pemimpin yang ideal.

\section{Nilai-nilai Asthabrata Sebagai Pendidikan Antikorupsi}

Implementasi nilai-nilai Asthabrata sebagai pendidikan antikorupsi bisa dilihat pada tabel sebagai berikut:

Tabel 1. Implementasi nilai-nilai Asthabrata sebagai pendidikan antikorupsi

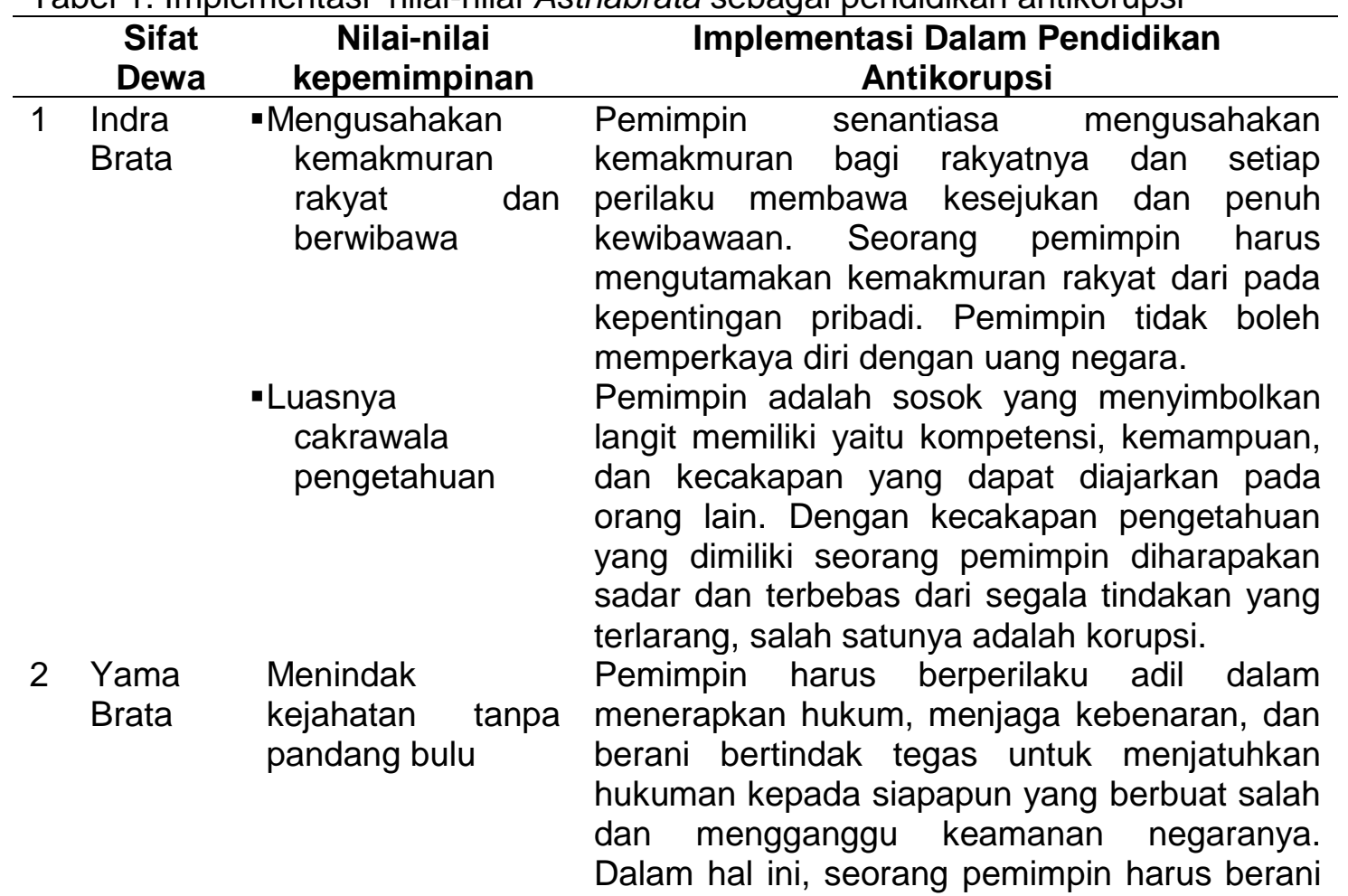


3 Surya Seperti matahari Brata sebagai sumber kehidupan

4 Candra Brata

5 Bayu Brata

6 Kuwera Brata memancarkan sinar dengan lembut. memberikan kehidupan kepada manusia ikut andil dalam upaya pemberantasan korupsi yaitu memberikan hukuman yang adil sesuai perbuatan yang dilakukan tanpa pandang bulu.

Pemimpin harus mampu memberikan bimbingan dan pendidikan agar manusia terhindar dari kegelapan. Seorang pemimpin harus membimbing dan memberikan contoh bawahannya agar terhindar dari tindakan korupsi. Perilaku tersebut berupa penanaman nilai-nilai antikorupsi yaitu kejujuran, tanggung jawab, keberanian, keadilan, keterbukaan, kedisiplinan, kesederhanaan, kerja keras dan kepedulian.

Menggambarkan Pemimpin hendaknya memiliki sikap lemah sifat bulan yang lembut, ramah tamah, murah senyum serta tidak mudah marah. Seorang pemimpin juga harus mampu menciptakan ketenangan dan ketentraman dalam lingkungannya. Dalam hal ini, ketika pemimpin menerapkan peraturan yang tegas terhadap tindakan korupsi, maka koruptor akan jera dan tidak ada rasa khawatir dan prasangka yang tidak baik dari masyarakat kepada pemimpin dan pemerintahan.

Seperti angin yang Angin atau udara merupakan sesuatu yang berguna bagi manusia untuk bisa bernafas. Kehadiran angin bisa dirasakan oleh manusia. Begitu juga dengan pemimpin, Keberadaannya bukan sebagai simbol dari kekuasaan. Pemimpin harus terjun menghadapi masalah dan peduli pada kondisi yang dihadapi oleh masyarakat. Kondisi ini seperti contoh kasus dana bansos yang dikorupsi oleh pejabat. Dana bansos yang harusnya untuk kebutuhan rakyat tetapi tidak sampai karena dikorupsi. Oleh karena itu, dengan mengimplementasikan nilai kepemimpinan banyu brata agar diharapkan mampu terbentuk empati seorang pemimpin, ketika rasa empati telah terbentuk maka seorang pemimpin tidak akan tega menggunakan sesuatu yang bukan haknya.

Menjaga dan Seorang pemimpin harus mengelola, mempergunakan memelihara, dan menjaga harta benda yang harta kekayaan dengan sebaikbaiknya untuk kepentingan kesejahteraan manusia dipercayakan kepadanya dengan baik demi kesejahteraan masyarakatnya. Sebagai seorang pemimpin tidak bisa dipisahkan dengan materi, baik itu materi pribadi maupun milik negara yang dikelolanya. Sifat kuwera kebahagiaan

dan brata ini menjadi pengendalian diri bagi seorang pemimpin agar terhindar dari tindakan dalam tata cara korupsi. Seorang pemimpin harus bijaksana pengendalian diri. dalam menggunakan dana atau uang dan selalu ada hasrat untuk mensejahterakan 


$\begin{array}{lll}\text { Baruna } & \begin{array}{l}\text { Pemimpin adalah } \\ \text { Brata }\end{array} & \begin{array}{l}\text { yang } \\ \text { membuka mata } \\ \text { dan pikiran secara } \\ \text { luas seperti } \\ \text { samudra }\end{array} \\ 8 \text { Agni } & \\ \text { Brata } & \text { Bersifat } \\ & \text { seperti api dalam } \\ & \text { menghadapi } \\ & \text { masalah } \\ & \text { merepresentasikan } \\ & \text { ketegasan dalam } \\ & \begin{array}{l}\text { pengelolan } \\ \text { mengambil } \\ \text { keputusan }\end{array}\end{array}$

masyarakat serta tidak menjadi pemboros yang akhirnya dapat merugikan negara dan masyarakat.

Seorang pemimpin memiliki pemahaman yang luas, harus terbuka terhadap pengetahuan. Dalam hal ini, dalam mengimplementasikan pendidikan antikorupsi, seorang pemimpin diharapkan mampu mengatasi setiap masalah dengan baik dengan pengetahuan yang dimilikinya. Ketika terjadi tindakan korupsi harus diselesaikan dengan baik dan tegas agar tidak terulang kembali.

Seorang pemimpin harus teguh dan tegak dalam prinsip dalam mengambil keputusan. la juga mampu objektif dalam menegakkan aturan, tegas dan tidak memihak. Dalam hal ini, seorang pemimpin harus menindak dengan tegas siapapun yang melakukan tindakan korupsi. Pemimpin dapat berperan dalam membuat peraturan terhadap tindakan korupsi.

\section{SIMPULAN}

Nilai-nilai yang terkandung dalam Asthabrata merupakan pedoman kepemimpinan yang ideal. Kepemimpinan dalam konsep Asthabrata merujuk pada delapan simbol alam yaitu: langit, matahari, angin, air, samudra, bulan, bintang dan api. Kepemimpinan Asthabrata dapat diterapkan sebagai pedoman dalam menyiapakan generasi emas Indonesia yang bebas dari korupsi. Langkah ini dilakukan dengan mengintegrasikan nilai-nilai yang terkandung dalam Asthabrata sebagai pendidikan antikorupsi. Pendidikan ini bertujuan sebagai pengendalian diri bagi generasi emas Indonesia agar terhindar dari tindakan korupsi.

\section{DAFTAR PUSTAKA}

Abdul Rahmat, Filsafat Pendidikan. Bandung: Manajemen Qolbun Salim. (2010), Aryawan, Wayan I. "Penerapan Kepemimpinan Asthabrata Dalam Pendidikan Dari Sudut Pandang Teori Konflik". Jurnal IImiah IImU Sosial. Vol. 7, No. 1 Juni 2021: 56-66.

As'ad, Anggoro, dan Virdanianty. (2011). "Studi Eksplorasi Konstrak Kepemimpinan Model Jawa: Asthabrata". Jurnal Psikologi. Vol. 38, NO. 2, Desember: 228239

Chaniago, Aspizain. (2017). Pemimpin dan Kepemimpinan: Pendekatan Teori dan Studi Kasus. Jakarta Pusat: Lentera IImu Cendekia

Hamzah, Andi. (1991). Asas-Asas Hukum Pidana,. Jakarta: Rineka Cipta

Handoyo, Eko. (2013). Pendidikan Antikorupsi. Yogyakarta: Ombak

Ka'abah Rifyal. (2007). "Korupsi di Indonesia". Jurnal Hukum dan Pembangunan Tahun ke-37 No. 1 Januari-Maret.

Rai Bagus \& Suarningsih. (2019). "Konsepsi Asthabrata Dalam Kepemimpinan Berlandaskan Tri Hita Karana". Jurnal Kajian Pendidikan Widya Accarya. ISSN No. 2085-0018

Setiadi, Wicipto. (2018). "Korupsi di Indonesia (Penyebab, Bahaya, Hambatan, dan Upaya Pemberantasan, Serta Regulasi)". Jurnal Legislasi Indonesia. Vol 15 No.3 November: $249-2602$. 
Sopyan, Hari. (2014). "Pemimpin Banten \&Tikut Pejarah Dana APBD". (kompasiana.com/harisopyan/552c429b6ea834a63a8b4567/pemipin-bantentikus-penjarah-dana-apbd)

Suaciartini Ayu Nyoman. "Penanaman Konsep Asthabrata Dalam Pendidikan Moral Antikorupsi". Senada 3 Fakultas Dharma Acarya IHDN Denpasar

Sukitman, Tri. (2016). "Internalisasi Pendidikan Nilai Dalam Pembelajaran (Upaya Menciptakan Sumber Daya Manusia Yang Berkarakter)". JPSD : Jurnal Pendidikan Sekolah Dasar. Vol. 2, No. 2.

Suyanto, Totok. (2005). "Pendidikan Anti Korupsi dan Pengembangan Pendidikan Antikorupsi 249 Budaya Sekolah". JPIS. Nomor 23 tahun XIII Edisi Juli Desember

Tim Penulis. (2012). Kamus Besar Bahasa Indonesia, Pusat Bahasa,Departemen Pendidikan Nasional, Gramedia Pustaka Utama.

Wilda Syahrul. (2017). "Filsafat Asthabrata: Implementasi Dalam Kepemimpinan Soeharto". Universitas Islam Negeri Syarif Hidayatullah Jakarta. Skripsi 